\title{
PEOPLE AND THE SEA: A VALUES PERSPECTIVE IN THE CONSERVATION MANAGEMENT OF MARITIME HERITAGE IN THE PHILIPPINES
}

\author{
Kristine Kate A. Lim* \\ Institute of Geographical Sciences, Department of Earth Sciences, \\ Freie Universitat Berlin, Germany \\ E-mail: kate.a.lim@gmail.com \\ Bobby C. Orillaneda**
}

Maritime and Cultural Underwater Heritage Division, National Museum of the Philippines, Philippines

E-mail: bobby.orillaneda@gmail.com

Catherine P. King ${ }^{* * *}$

Institute for Scientific Archeology, Eberhard Karls University of Tübingen, Germany

E-mail: catherinemayking@gmail.com

Published online: 30 July 2021

To cite this article: Lim, K. A., Orillaneda, B. C. and King, C. P. 2021. People and the sea: A values perspective in the conservation management of maritime heritage in the Philippines. International Journal of Asia Pacific Studies 17 (2): 39-73. https://doi.org/10.21315/ijaps2021.17.2.3

To link to this article: https://doi.org/10.21315/ijaps2021.17.2.3

\begin{abstract}
As demonstrated in archaeology, underwater cultural heritage (UCH) has provided significant contributions towards the understanding of heritage connections across the globe. However, the development of the discipline in the Philippines has also been hampered by confusing legalities, treasure hunting activities, and financial constraints that diminish the influence of its impact and potential reach. More so, the effects of natural hazards, climate change, and other human activities on UCH have not yet been fully documented, making it more susceptible to potential threats and destruction. The COVID-19 pandemic makes archaeological campaigns and monitoring even more difficult. These considerations make Philippine UCH


vulnerable and raise questions whether its contribution will still be relevant for the present and future generations. This article provides a status update of underwater archaeological activities and synthesises the challenges of managing UCH in the Philippines in the past 40 years. It outlines the practices, partnerships, and transitions made by various stakeholders in response to the growing discipline and community interest. This article problematises the value ascription of these stakeholders to UCH as seen in conventional arrangements, development of policies, and bureaucratic set-ups. The applicability of the values-led theory and the peoplecentred management model is examined given the traditional valuing of UCH that is material or fabric-based. The gaps pointed here are opportunities to build a shared stewardship view that connects UCH in the entirety of people and the sea wellbeing.

Keywords: Philippine archaeology, underwater cultural heritage, people-centred approach, values-led, heritage conservation

\section{INTRODUCTION}

The protection of Philippine underwater cultural heritage (UCH) in terms of archaeological practice in the last four decades has been challenging and complex. For one, its fundamental principles were only reinforced in 2010 through the passage of the National Cultural Heritage Act of 2009 where $\mathrm{UCH}$ may be regarded as an "archaeological area" (Republic Act [R.A.] No. 10066 [Republic of the Philippines 2010]). Before this, while cultural heritage was not defined, cultural properties such as antiques, National Cultural Treasures, and Historical Sites were protected under R.A. No. 4846 or the "Cultural Properties Preservation and Protection Act of 1966" [amended in 1974] (Malilong and Villanueva 2017). Accordingly, it considers "ships or boats in part or in whole" as cultural properties (Presidential Decree No. 374: Section 3.a). In 1982, an Underwater Archaeology Guideline was formulated and "later expanded to its present form as the Rules and Regulations for Underwater Archaeology in Exploration and Excavation in Philippines Waters" (Orillaneda 2012: 89). These guidelines serve as a response to the need for regulatory procedures to ensure the proper conduct of underwater explorations and partnership agreements made by the government through the National Museum of the Philippines (NMP) and its counterpart proponents (see Orillaneda 2012; Orillaneda and Ronquillo 2011).

In 1988, the Protection of Underwater Cultural Heritage Act (Senate Bill [S.B.] No. 695) was proposed "to provide a permitting system for underwater exploration and excavations aside from establishing definite 
archaeological and scientific procedures to follow." This bill acknowledged the need for an underwater archaeological permitting system, different from systematic terrestrial excavations that would follow definite scientific procedures (Ronquillo 1990: 132). However, this bill was not passed into law. In 2019, an act strengthening the NMP or R.A. No. 11333 passed into law, repealing R.A. 8492 (An Act Establishing a National Museum System) that transfers certain regulatory functions of the NMP to the National Commission for Culture and the Arts (NCCA). This law covers the regulation for archaeological practice. At this time of writing, the administrative transition is ongoing $^{1}$ though it is unclear if NCCA will fully adopt the existing regulatory manual of the NMP (i.e. QMS-CPRD Manual [National Museum of the Philippines 2016]).

Internationally, the Philippines has yet to sign the UNESCO (United Nations Educational, Scientific and Cultural Organization) 2001 Convention on the Protection of Underwater Cultural Heritage (UNESCO 2013). UNESCO defines UCH as "all traces of human existence having a cultural, historical or archaeological character which have been partially or totally under water, periodically or continuously, for at least 100 years" (2001 UNESCO Convention, Article 1 [UNESCO 2013]). Under the Philippine cultural heritage law (R.A. No. 10066, Article 2) (Republic of the Philippines 2013), this UNESCO description is reflected in the following terms and definitions:

(c) Antique shall refer to a cultural property found locally which is one hundred (100) years in age, more or less, the production of which has ceased.

(d) Archaeological area shall refer to any place, whether above or under ground, underwater or at sea level, containing fossils, artifacts, and other cultural, geological, botanical, zoological materials which depict and document culturally relevant paleontological, prehistoric, and/or historic events.

(1) Cultural heritage shall refer to the totality of cultural property preserved and developed through time and passed on to posterity.

In principle, Section 30 (Article VII) states that "all cultural properties found in terrestrial and/or underwater archaeological sites belong to the State."

In contrast with the UNESCO definition, the Philippine UCH, since the first policy on cultural heritage, can be regarded for its fundamental principles anchored on antiquity and state ownership. However, due to 
budgetary constraints, the practice of underwater archaeology in the country has often been led by not just the state, but also private proponents as financial sponsors (Calderon 1989; Orillaneda and Ronquillo 2011; Ronquillo 1990; Orillaneda and Jago-on 2017). Perennial problems of looting, treasure hunting, and antique collecting have also been rampant (e.g., Orillaneda and Ronquillo 2011; Orillaneda 2012; Ronquillo 1990). With additional concerns on natural hazards and climate change (see Spalding 2011; Wright 2016), especially in a vulnerable country like the Philippines (Capili, Ibay and Villarin 2005; Villarin et al. 2016), increasing threats to UCH also place it at a higher risk of danger and destruction.

This article, therefore, assesses the conventional approaches in Philippine UCH research and management in the last four decades. By consolidating and summarising the data, we also evaluated the present status as well as past and present motivations to learn from these experiences. We moreover question how we can fully protect Philippine UCH status and improve conservation management initiatives for the community and environmental wellbeing. A values-led and people-centred approach are used as an alternative framework to strategise for more a sustainable and culturally responsive UCH protection initiatives. Despite the absence of a targeted and direct policy, the Philippines can still pro-actively protect and promote the relevance of maritime history and safeguard our shared heritage.

\section{MILESTONES IN PHILIPPINE UNDERWATER ARCHAEOLOGY}

The beginnings of underwater archaeology in the Philippines can be traced back to 1967 (as shown in Figure 1), with a reported 1647 galleon shipwreck at Albay Gulf suspected as the Santo Domingo (Dizon 1992; Alba 1984; Lopez 1967) (as shown in Figure 2). Years later, a 20th century CE (Common Era) regional trading vessel was found in Iloilo (Conese 1989; Conese and Nicolas 1984). In both cases, the NMP collaborated with other government agencies and private groups due to the absence of a targeted underwater archaeology policy and agency. Thus, the recovery and documentation methods were not systematic, and the results were not academically published. 


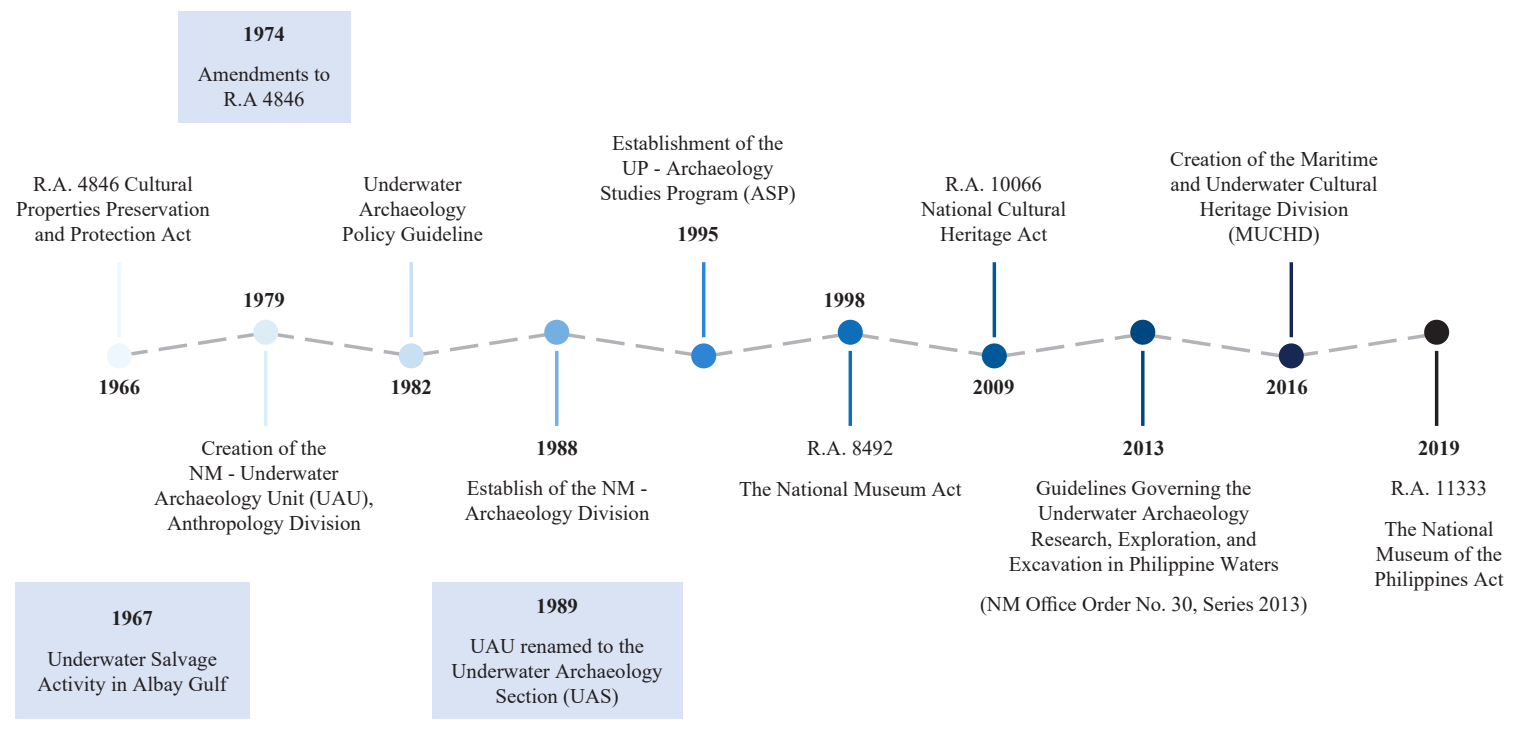

Figure 1: Significant years and events in the practice of maritime and underwater archaeology in the Philippines.
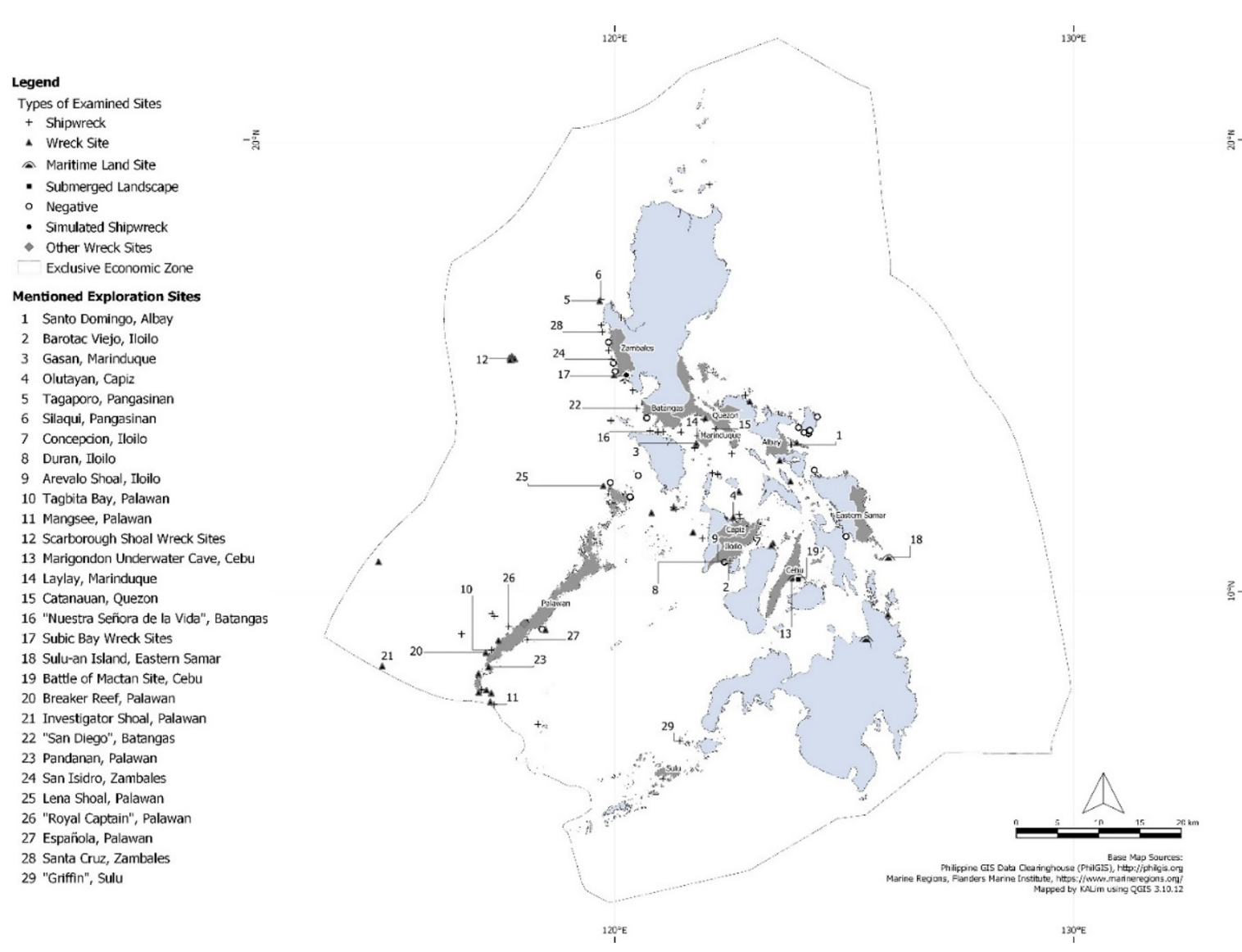

Figure 2: Map of maritime and underwater archaeological explorations by the NMP (approximate location points) including the major archaeological excavations conducted. 
In 1979, the NMP created the Underwater Archaeology Unit (UAU) under the Anthropology Division, after several museum personnel graduated from an underwater archaeology training course in Thailand (E. Dizon 2021 personal communication 14 January 2021; Conese 1989; Alba 1984) (as shown in Figure 3). The unit's first project was to excavate a 16th CE shipwreck in Gasan, Marinduque Island (Alba 1990; Conese 1989; Conese et al. 1981). The UAU also conducted explorations in Capiz, Pangasinan, and Iloilo between 1983 and 1985 (Conese 1989).

The UAU collaborated with private groups "that could financially support exploration and excavation projects in exchange for a share of recovered materials, reflecting the fact that the government could not provide funds for fieldwork and stop the rising incidence of shipwreck looting" (Orillaneda and Ronquillo 2011: XX). In 1982, an Underwater Archaeology Policy Guideline was created to provide the basis for this cooperative relationship. The Guideline outlines the rules and regulations related to the issuance of permits for outside parties, including methodologies used to engage underwater archaeological activities in the Philippines. The 1982 Guideline was updated in 2013 as Guidelines Governing the Underwater Archaeological Research, Exploration, and Excavation in Philippine Waters (NM Office Order No. 30 Series 2013).

In 1988, the restructuration of the NMP resulted in the formation of the Archaeology Division, which was separated from the Anthropology Division, and by 1989, the UAU was reorganised as the Underwater Archaeology Section (UAS). The section's first project was to revisit the Gasan shipwreck to improve recording methods and recover more artefacts. The succeeding years of 1990 until 2001 were considered the peak of Philippine underwater archaeology due to the number of significant excavation projects (as shown in Figure 2: item 20-28) that contributed to the documentation of the Philippines' maritime past (Orillaneda and Ronquillo 2011).

In 1995, the first archaeology graduate school in the country opened. The University of the Philippines-Archaeological Studies Program (UP-ASP) offered an underwater archaeology course taught by Dr. Eusebio Dizon, its first director and the head of the UAS. In 2018, additional maritime and nautical archaeology subjects were listed and conducted by Dr. Ligaya Lacsina (E. Dizon 2020, personal communication, 7 August 2020). ${ }^{21}$

From 2002 until 2016, the UAS projects focused more on surveys and site investigations. Two excavations were unfinished due to insufficient funding (Tagbita Bay and Mangsee shipwrecks), while the investigation 
of 13th to 16th century CE wreck sites and World War II (WWII) remains was halted due to territorial and maritime dispute between the Philippines and China in the West Philippine Sea (Lacsina et al. 2011; Orillaneda and Soriano 2006; 2010). In 2011, the first submerged landscape archaeological survey was carried out with funding from the National Geographic Society (NGS) (Peterson, Jalandoni and Rocha 2017; Rocha et al. 2017). In 2013, contrary to the previous underwater archaeology projects that involved private proponents and external funders, the NMP solely funded and led a shipwreck excavation in Boac, Marinduque (Jago-on et al. 2014).

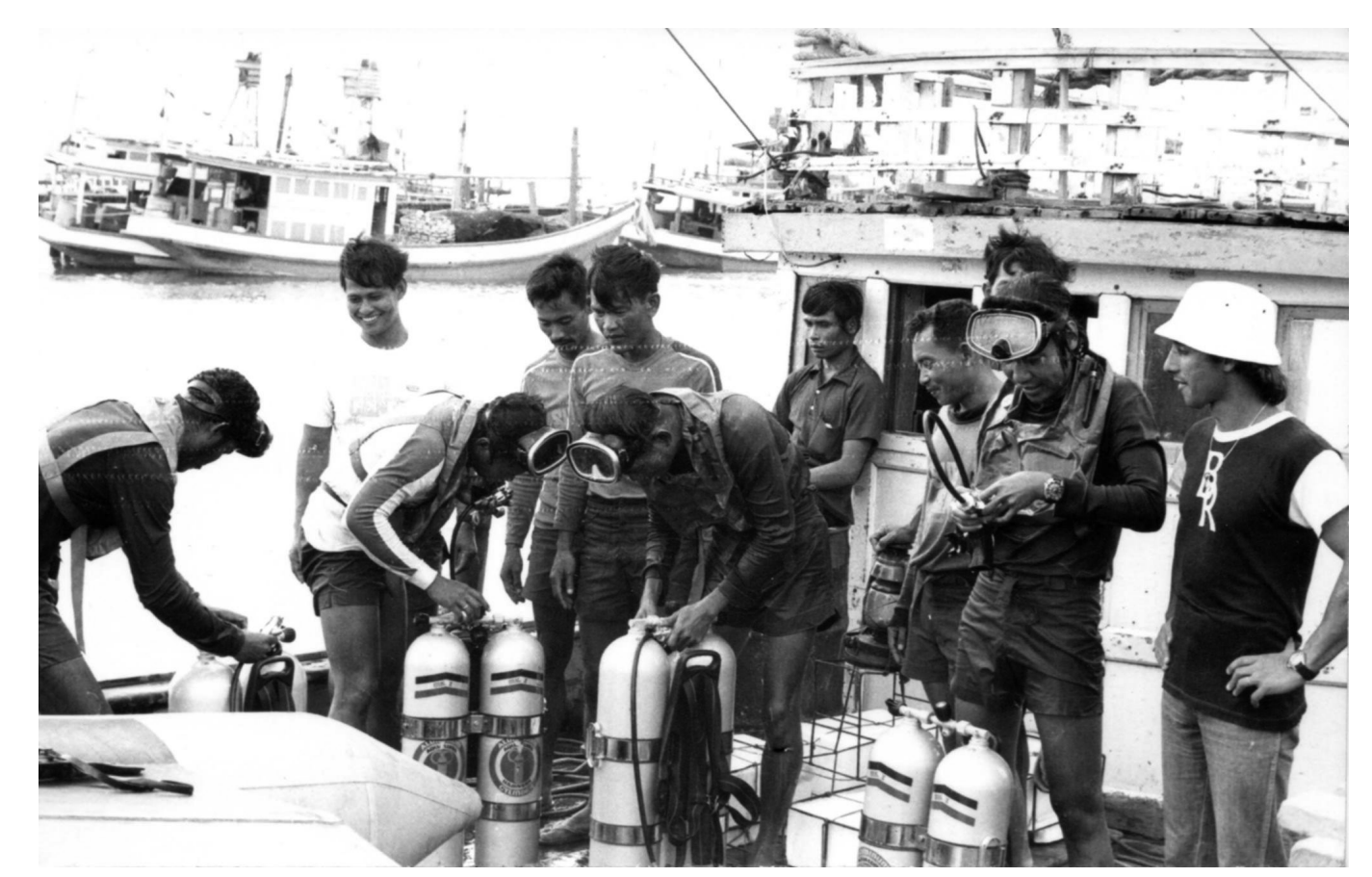

Figure 3: Participants of the first Training Course in the Conservation of Underwater Archaeological Objects from 11th December 1978 to 8th March 1979 in Thailand. Second to the right in this photo is Eduardo Conese, the first head of the UAU-NMP.

Source: SEAMEO-SPAFA from its 50th Anniversary Collection image archives.

As part of the NMP's institutional reorganisation, the UAS was renamed and restructured as the Maritime and Underwater Cultural Heritage Division (MUCHD) in 2016. The MUCHD mandate states that it will cover "archaeological research not only with shipwrecks but also includes coastal and foreshore archaeological sites related to ancient maritime activities as well as the assessment, investigation, and protection of World War II shipwrecks" (Orillaneda and Jago-on 2017: 259). A section formerly composed of six staff expanded to 22 staff, but not all positions are filled as of this time of writing. 
Besides the Catanauan shipwreck excavation (Orillaneda and Jagoon 2017; Jago-on and Orillaneda 2016) and the re-investigation of the Manila galleon Nuestra Señora de la Vida (Lacsina and Jago-on 2019), the MUCHD took on world war-related collaborative projects (Ureta et al. 2019). The MUCHD also resurveyed the WWII wrecks in Subic Bay and re-assessed the USS Majaba shipwreck (King et al. 2018, 2019). The NMP moreover launched two projects related to the Spanish arrival in the Philippines solely with government funding. One is the investigation of Sulu-an Island (Lacsina, Orillaneda and Bersamira 2017) (as shown in Figure 2: item 18), a landing site among Ferdinand Magellan's fleet (Bergreen 2003), and the other is the Battle of Mactan site, where Spanish forces and local inhabitants fought in 1521 (see Angeles 2007; Jocano 1975).

The MUCHD continuously engages the public through museum exhibitions and talks (see Ureta 2019; King 2018a, 2018b, 2019). At present, no field activities are allowed. The MUCHD focuses on developing new exhibitions, artefact analysis, and collection management to increase online visibility $^{32}$ as well as research and publications.

\section{UCH RESEARCH PRACTICE IN THE PHILIPPINES}

In the last four decades, underwater archaeological practice in the Philippines has served as one of the disciplinary facets of maritime archaeology (see Green 2004; Muckelroy 1978). Based on the NMP data, we categorised the types of archaeological explorations and excavations in the Philippines related to $\mathrm{UCH}$ (as shown in Table 1). UCH-related projects are mainly dominated by shipwreck investigations (as shown in Figure 4), followed by wreck sites where underwater research is geared towards locating or salvaging the cargo and utilitarian items from the vessel. Although the MUCHD's expanded mandate (covering coastal and foreshore archaeological sites) came in later, the UAU/UAS projects were not confined to shipwreck investigations as they also included several land investigations related to archaeological research underwater.

In the past, joint ventures with collaborators provided financial, technical, and manpower resources to pursue underwater archaeological activities. Proponents may be private or local companies or individuals who sign a Memorandum of Agreement/Understanding with NMP to keep some of the archaeological recoveries in exchange for financing a project. Among the more successful joint ventures is the long-term partnership with Franck Goddio and his team in major UCH surveys and excavations, which 
remained consistent while the proper conduct of underwater archaeological investigations is assured (see Jago-on and Bersamira 2018; Dizon 2003; Goddio et al. 2002; Goddio 1996).

Table 1: Categories of examined sites by UAU/UAS/MUCHD

\begin{tabular}{ll}
\hline Types of examined sites & $\begin{array}{l}\text { General definition according to summarised reports and } \\
\text { explorations conducted }\end{array}$ \\
\hline Shipwreck & $\begin{array}{l}\text { Synonymous to a sunken vessel or a ship with intact or } \\
\text { fragmented identifiable remains, related cargo, and ship } \\
\text { materials found underwater }\end{array}$ \\
Sites explored underwater that showed evidence of \\
significant number of cultural materials, but no vessel found \\
Maritime-related vessels, structures or settlement sites \\
investigated or co-investigated by UAU/UAS/MUCHD that \\
are situated along the coast or other waterlogged conditions \\
(lakes, rivers, swamps, or peat) \\
An underwater cultural landscape or feature that was exposed \\
in the past \\
Submerged landscape site & $\begin{array}{l}\text { Sites investigated underwater that did not produce or lacked } \\
\text { enough archaeological materials for full investigation or the } \\
\text { intended research site or wreck was not found/located }\end{array}$ \\
Negative & $\begin{array}{l}\text { Shipwrecks re-assessed for educational and exhibition } \\
\text { purposes for the public } \\
\text { Comprise of other submerged transport of infrastructures } \\
\text { underwater }\end{array}$ \\
\hline
\end{tabular}

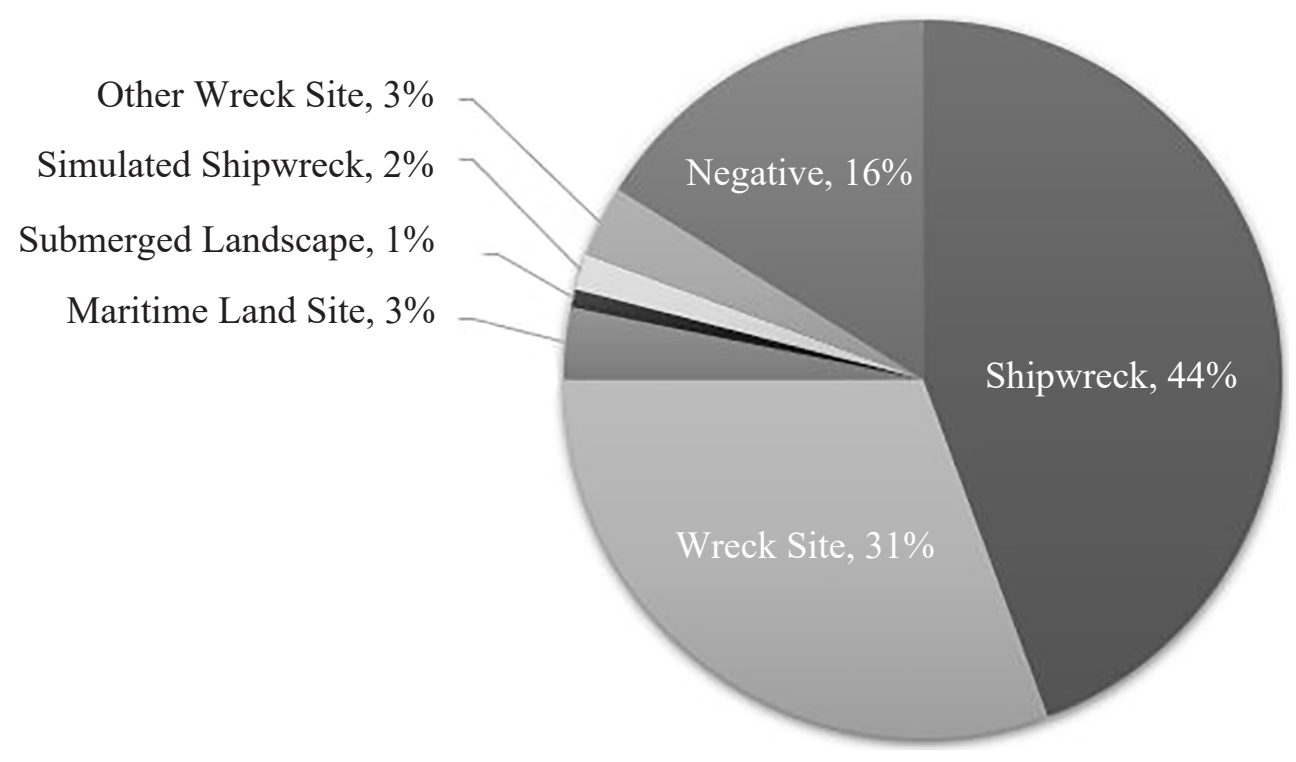

Figure 4: An estimated proportion of investigated site types of UAU/UAS/MUCHD over the past four decades. 
While the NMP lacks highly technical survey and excavation equipment to carry out fast and deep-site surveys that some proponents provide, the NMP ultimately decides the conduct of the project (E. Dizon 2020, personal communication, 7 August 2020). As part of the National Archaeological Collection, the NMP moreover kept all rare and unique items and 50\% of artefacts. With the passage of the R.A. No. 10066, only Grade III objects can be shared for research and exhibition purposes. Archaeological and ethnographic materials are presumed Important Cultural Property and "are protected from destruction and modification" (Tantuico 2020: 39). For specific definitions, see the following excerpt:

Section 7. Categories - The Cultural Property of the country whether public or privately owned, movable or immovable, and tangible or intangible shall be categorised as follows:

The following shall be declared as Grade I level:

(a) World Heritage Sites;

(b) National Cultural Treasures;

(c) National Historical Landmarks;

(d) National Historical Shrines; and

(e) National Historical Monuments.

The following shall be declared as Grade II level:

(a) Important Cultural Properties - shall refer to a cultural property having exceptional cultural, artistic, and historical significance to the Philippines as shall be determined by the National Museum, the National Historical Commission of the Philippines, the National Library of the Philippines and/or the National Archives of the Philippines.

The following shall be declared as Grade III level:

(Section 7.1.) All other cultural property in the Registry of Cultural Property not declared as Grades I or II shall be Grade III cultural property deemed-Important Cultural Property, unless otherwise delisted. 
The following shall be declared as Uncategorised Property:

(Section 7.2.) Undeclared property not falling under the presumption of Important Cultural Property, but contains characteristics that will qualify them as such shall be registered in the Philippine Registry of Cultural Property.

\section{CHALLENGES IN UCH MANAGEMENT}

Managing UCH is a difficult task because of the complexities in dealing with practical concerns (Frigerio 2013; Orillaneda and Ronquillo 2011; Green 2004). Lack of adequate funds and of qualified personnel, weak legislation and policy enforcement, and insufficient communication and demonstration of relevance are the common factors that limit the potential of not just underwater archaeology but also the whole discipline (Orillaneda and Jago-on 2017; Flecker 2017b; Mijares 1997; Orillaneda 2012; Orillaneda and Ronquillo 2011; Ronquillo and Dizon 1999; Ronquillo 1992). Interrelated challenges such as treasure hunting, illicit trade, antique collecting, miseducation and poverty (Lim 2019; Estrella 2018; Bersales 2016; Barretto-Tesoro 2000) further complicate UCH management.

This section elaborates on these relational challenges, which, according to Ronquillo (1992: 133), "compromise the preservation and protection of maritime cultural resources in the Philippines." Figure 5 outlines these interrelated concerns with reference to budget, people and administration, as well as the conventional approaches used to address the challenges related to UCH (as shown in Figure 6).

\section{Managing the Profession}

Since 1967 , the primary strategy to ensure professional conduct in underwater exploration activities is through public-private joint ventures (Ronquillo 1990; Calderon 1989). Underwater archaeology is an expensive endeavor. It requires practitioners to be knowledgeable and trained in the discipline of archaeology and material conservation, professionally certified in recreational and/or scientific diving, possess basic SCUBA (Self-Contained Breathing Apparatus) skills and documentation gears/equipment, and enough financial resources for fieldwork (on land or onboard) (see Green 2004). During the early years of the UAU/UAS, the main concern was the lack of dive equipment to conduct underwater archaeological research and explorations. 
After four decades, the new MUCHD was finally able to obtain complete sets of SCUBA diving equipment, air tanks, compressors, metal detectors, underwater cameras, a side-scan sonar and a Rigid Inflatable Boat (RIB).

The lack of equipment is also related to the lack of human resources or experts who are knowledgeable and skilled in conducting underwater archaeology. Collaborations with foreign entities and local authorities like Local Government Units (LGUs), Department of Environment and Natural Resources (DENR), Philippine Navy (PN) and the Philippine Coast Guard (PCG) were and are still warranted (Orillaneda and Ronquillo 2011). While some arrangements work, there were also weaknesses due to opposing priorities of the stakeholders and the lack of knowledge on protocols and coordination work (see Ronquillo 1990; Calderon 1989).

It is also costly to sustain and manage the conservation of archaeological assemblages as explorations increase. Artefact collection may require specialised equipment, improved documentation techniques, storage facilities, and a laboratory to stabilise and ensure the integrity of archaeological materials found on marine sites (see Mak 2014; Shott 2014; Hamilton 1999). Rightly so, this may also require additional courses and personnel that focus on material conservation and digital archaeology (see Green 2004; Rodgers 2004; Bourque et al. 1980).

At present, upgrading the artefact collection holdings of the MUCHD is a testament to the four decades of underwater archaeology practice in the Philippines. Even so, none of the institutions in the Philippines have a laboratory solely dedicated to the conservation and restoration of underwater archaeological materials. Inadequate funding and qualified personnel may still be the reason for this insufficiency (see Orillaneda and Ronquillo 2011). Meanwhile, the development of related programmes such as the Cultural Heritage Studies graduate course in the University of Santo Tomas (UST) is an inviting opportunity to build on specialisations in museum development and cultural resource management ${ }^{43}$ that may enable more field professionals.

\section{Dealing with the Bureaucracy}

According to Ronquillo (1990: 132), "joint ventures with private entities characterised the National Museum's entry into underwater archaeological activities in 1967 and have continued to be the normal practice" in the succeeding years. However, while some arrangements worked, "other problems arose due mainly to the absence of specific policies by the National Museum on the matter". As a result, the 1986 policy guidelines 
were formulated, implemented, and updated as of 2013. Simultaneously with the implementation of Republic Act (R.A.) No. 10066, these policies demanded stricter regulatory provisions and higher costs in conducting underwater archaeological activities, given the categories and definitions of cultural properties. Despite these commendable efforts, the 2013 policy guidelines can be more specific in determining Grade III materials or undeclared important cultural properties because such materials "can still be exported and presumably sold with the NMP approval" (Flecker 2017b: 18). As previously mentioned, currently there is a transition of regulatory powers from the NMP to the NCCA. It is unclear if the 2013 policy guidelines on underwater archaeological activities will be adopted or changed.

The R.A. 10066 (Section 30.d) also requires an Archaeological Impact Assessment (AIA) under the Environmental Impact Assessment (EIA) System. This provision is specifically applicable to "any government or nongovernment infrastructure project or architectural site development". Besides the limited number of archaeologists, the lack of awareness by both developers and government authorities inhibits its full implementation (see Ronquillo 1992). With the ongoing infrastructure, tourism, and other land development projects, AIAs should be reinforced and actively pursued under the EIA System or reviewed as a separate heritage impact assessment requirement by the government (see ICOMOS 2011; Patiwael, Groote and Vanclay 2019).

There is also much to learn about Southeast Asian experiences concerning UCH legislation enactment, and management approaches (see Pearson 2019; Flecker 2017b). For one, treasure hunting is still legal in the Philippines, albeit confined to terrestrial sites. Together with the illicit trade of antiquities, they comprise an economic opportunity for low-income locals who earn from it, seemingly with no other livelihood opportunities (Estrella 2018; Mijares 1997). Even though treasure hunting is regulated, this activity adversely impacts cultural properties and educational and social systems (Lim 2019; Estrella 2018; Bersales 2016). More than half of the UCH-related documents referenced in this article reported looting and other disruptive activities (e.g., dynamite fishing, destructive interference of the site/material) prior and during systematic or salvage archaeological activities. Some reports also identified authorities allegedly involved in the plunder of cultural properties either as treasure hunters and/or as illegal traders or sellers of archaeological materials. Some of these accounts were written in the reconnaissance reports of Carasanan (coast guard) (Orillaneda 2000) (as shown in Figure 2: item 21); Pandanan (local police) (Cuevas 1993) 
(as shown in Figure 2: item 29) and Jolo (Philippine Craft Fast, affiliated with the PN) (Batoon 2005) (as shown in Figure 2: item 30). On top of this, the Chinese claims over the Spratly Islands and the Scarborough Shoal have also impacted UCH research and management efforts in these areas (Flecker 2017a, 2017b; Jing and Li 2019).

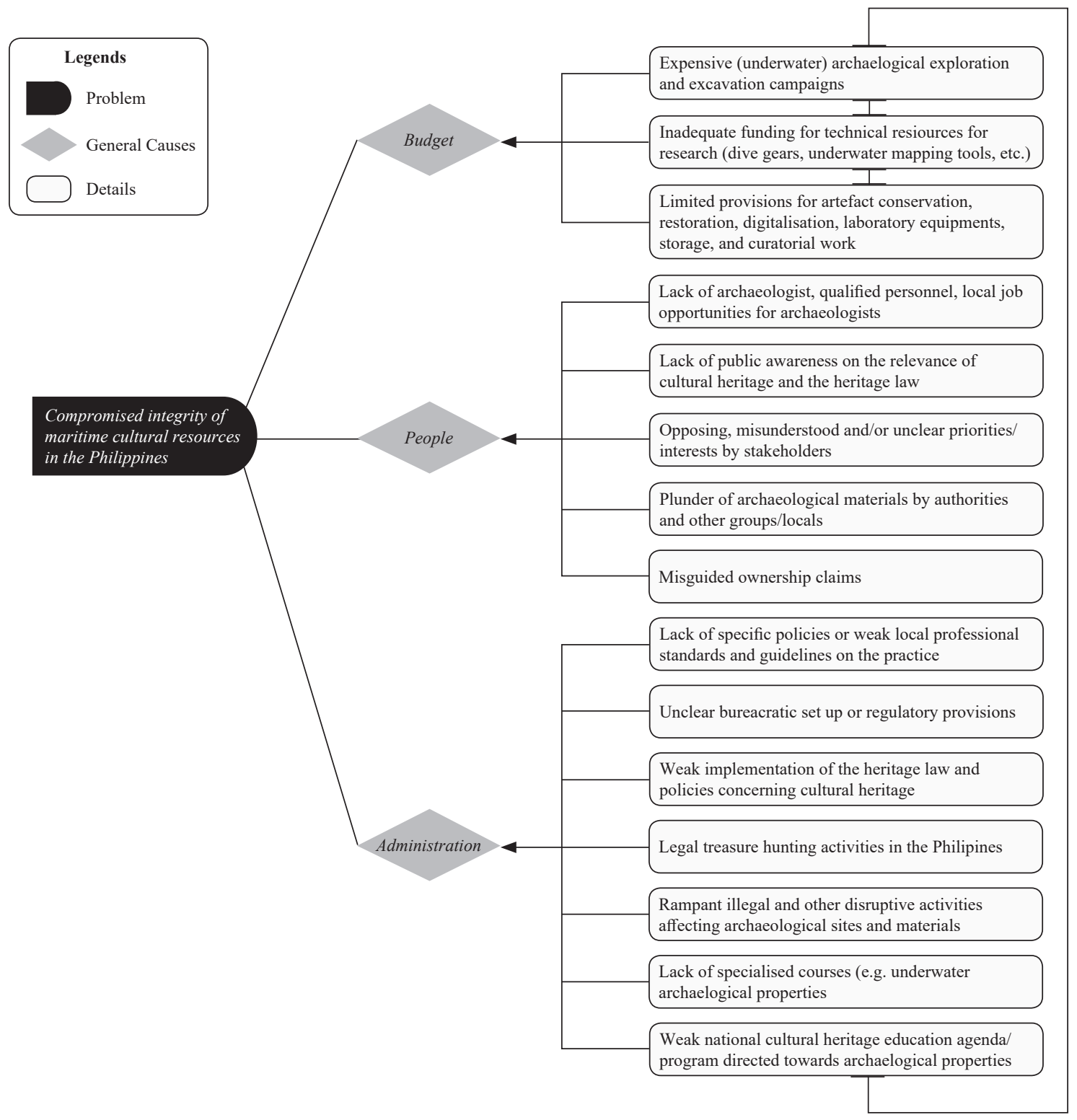

Figure 5: Relational diagram of challenges in Philippine UCH research and conservation management. 


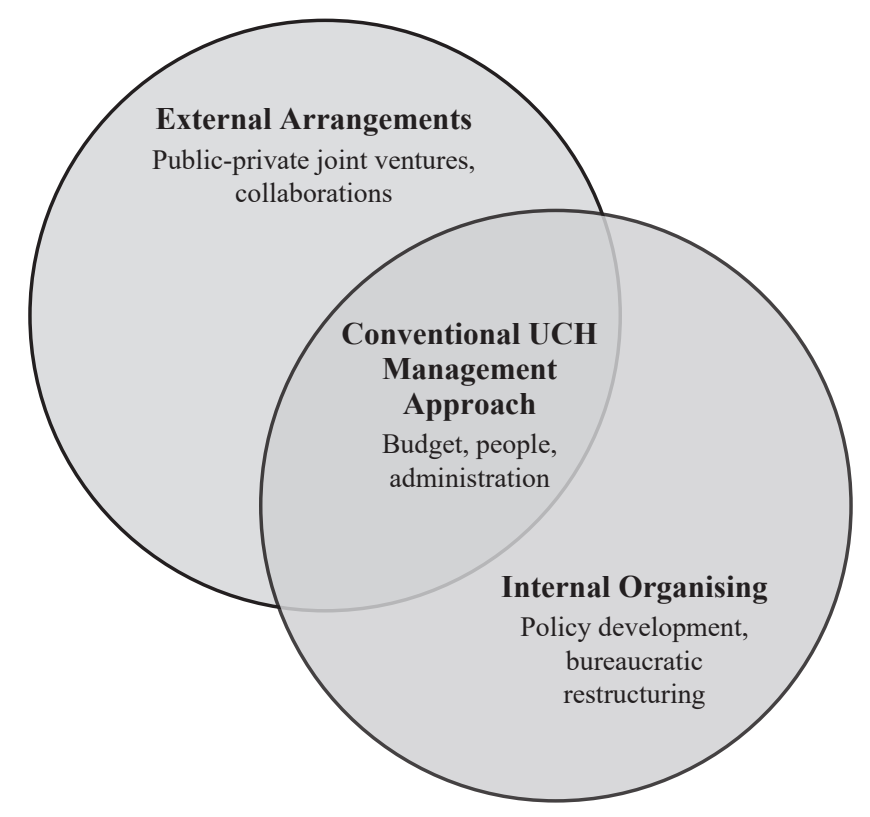

Figure 6: A summary of the conventional UCH management approach.

\section{Valuing Maritime Archaeological Remains}

$\mathrm{UCH}$ can have various meanings to different people. In determining these meanings, Mason (2008: 305) subscribes to the values-centred theory "to describe the variety of meanings, uses, and functions ascribed to heritage places in contemporary society". He adds that a place can have different heritage values depending on a variety of legitimate concerns of the recognised stakeholders. As cultural values strongly shape public attitudes and decisions, they therefore form "the traditional core of conservation interest" (Mason 2008: 305).

The values-centred theory was a response to the critique of Western approaches towards heritage conservation management that is material or fabric-centred, as embodied in the 1964 International Charter for the Conservation and Restoration of Monuments and Sites [Venice Charter, (ICOMOS 1974)] (Wijesuriya 2017; Poulios 2010). Material or fabric centeredness is the overemphasis on heritage materiality or what Wijesuriya termed as "secularization of heritage", which places importance on "fixing heritage places [rather] than probing how and why societies use heritage" (Wijesuriya 2017: 1-2). Several individuals and groups have challenged this traditional and Eurocentric emphasis on the materiality in heritage conservation and proposed instead to focus on people's wellbeing and inclusive development (Avrami et al. 2019; Wijesuriya 2017; ICOMOS 2014; ICOMOS 2013; Araoz 2011; Mason 2006; Avrami et al. 2000; 
de la Torre 2002; de la Torre and Mason 1999). In this way, the proposal addresses the role of people and the need to engage communities in heritage management and conservation (Court and Wijesuriya 2015; Wijesuriya 2015).

The values-centred theory emphasises heritage values, which can generally be defined as the meaning and significance of heritage resources (Díaz-Andreu 2017; Burra Charter 2013: 2; Manders, Tilburg and Staniforth 2012: 3; de la Torre and Mason 2002; ICOMOS 2004: 3) (as shown in Table 2). This theory is complementary to the people-centred approach that is defined as "a management model in which people and their livelihoods are at the core of decision making" (Wijesuriya 2015: 24). The people-centred approach thus upholds heritage values based on people's perspectives, which reconnect and establish the link between heritage and people (Wijesuriya 2017: 7). Scholars have attempted to typologise heritage values according to themes of significance to people, such as historical, aesthetic, economic, social, scientific, symbolic, etc. (e.g., Fredheim and Khalaf 2016; Mason 2002). These are "methods of identifying, articulating, and establishing cultural significance" where "cultural significance is used here to mean the importance of a site as determined by the aggregate of values attributed to it" (de la Torre and Mason 2002: 1). In UCH, the assessment of values enables the identification of the direct and indirect uses as well as the nonmarket services of this type of heritage. When these values are ascribed by different people, community perspectives are considered especially on the typical question of what the social and economic benefits of heritage are (Claesson 2011: 62).

To illustrate the assessment of heritage values in UCH, Manders et al. (2012: 6) discussed the concept of memory value in a shipwreck. Shipwreck significance may be less for the locals and local historical value than at the national and international levels. WWII wrecks, for example, retain a high collective memory value, especially for national and international governments. In the Philippines, international funders/collaborators such as Navigea Ltd. took an interest to locate WWII shipwrecks and sought joint ventures with the NMP (e.g., Ureta et al. 2019; Lacsina et al. 2011). Other values can also be considered by archaeologists when crossing from scientific appreciation to cultural heritage management. For aesthetic value, while it "is difficult and highly subjective value to ascertain", UCH sites can be assessed for their educational and exhibition suitability (Manders et al. 2012: 6-8). They can also be transformed for their tourism value (e.g., Argyropoulos and Stratigea 2019; Vladimirova 2016) which can counter the idea that UCH economic value can only be expressed by appraising the artefacts' monetary value. 
Table 2: An overview of various determinations of heritage significance

\begin{tabular}{|c|c|c|}
\hline References & Term/s & Definition \\
\hline $\begin{array}{l}\text { de la Torre and } \\
\text { Mason (2002) }\end{array}$ & Value & $\begin{array}{l}\text { Can be defined simply as a set of positive } \\
\text { characteristics or qualities perceived in cultural } \\
\text { objects or sites by certain individuals or groups } \\
\text { (p. 4). }\end{array}$ \\
\hline ICOMOS (2004) & Cultural values & $\begin{array}{l}\text { The meanings, functions, or benefits ascribed } \\
\text { by various communities to something they } \\
\text { designate as heritage, and which create the } \\
\text { cultural significance of a place or object (p. } 3 \text { ). }\end{array}$ \\
\hline ICOMOS (2013) & $\begin{array}{l}\text { Cultural } \\
\text { significance }\end{array}$ & $\begin{array}{l}\text { Means aesthetic, historic, scientific, social, } \\
\text { or spiritual value for past, present or future } \\
\text { generations. It is embodied in the place itself, } \\
\text { its fabric setting, use, associations, meanings, } \\
\text { records, related places and related objects. } \\
\text { Places may have a range of values for different } \\
\text { individuals or groups (p. 2) }\end{array}$ \\
\hline $\begin{array}{l}\text { Manders, Tilburg } \\
\text { and Staniforth (2012) }\end{array}$ & $\begin{array}{l}\text { Value related } \\
\text { to cultural } \\
\text { significance }\end{array}$ & $\begin{array}{l}\text { Value can be considered in terms of not only the } \\
\text { economic value of a site, but also its aesthetics } \\
\text { and historical values and its overall uniqueness } \\
\text { or relevance. Value also refers to an ethical } \\
\text { quality; the significance by virtue of material } \\
\text { and inner standards that a society often accords } \\
\text { to certain objects, places, and stories associated } \\
\text { with its ancestral past (p. } 3 \text { ) }\end{array}$ \\
\hline $\begin{array}{l}\text { Díaz-Andreu } \\
\text { (2017) }\end{array}$ & Heritage values & $\begin{array}{l}\text { Meanings and values that individuals or groups } \\
\text { of people bestow on heritage (including } \\
\text { collections, buildings, archaeological sites, } \\
\text { landscapes, and intangible expressions of } \\
\text { culture, such as traditions) (p. 2). }\end{array}$ \\
\hline
\end{tabular}

In the Philippines, the comprehensive documentation of Subic Bay UCH sites has revealed "late 19th century and WWII ships, aircrafts and other vehicle wrecks belonging to the United States of America (USA), Japan and the Kingdom of Spain" (King et al. 2019: 9-10). These sites are presumed important cultural properties under the jurisdiction of the NMP as they have been exposed to natural and anthropogenic inventions, which have led to gradual degradation and they, therefore, need immediate regulatory policies and management plans. A general values assessment was carried out in Subic Bay UCH where "value suggests usefulness and benefits" (Mason 2002: 8). Mason (2002: 8-9) provided the following clarificatory notes: (1) "values change", (2) "values cannot be objectively measured", and (3) "while subjectivity and contingency of heritage values make it difficult 
to establish a clear framework or even a nomenclature of values, this is what is needed to facilitate the assessment and integration of different heritage values in conservation planning and management".

Mason (2002: 10) further suggests outlining a "provisional typology" related to socio-cultural and economic values - "which is neither exhaustive nor exclusive" to initiate the discussion. Similarly, Claesson (2011: 65-66) suggested that as a start of the valuation process, broadly defining the "functions" and "services" of cultural heritage can provide a general idea of its possible importance to potential stakeholders. General typologies were listed to examine Subic Bay's shipwreck preservation and management potential. Stakeholders were also identified with current dealings or those likely to ascribe various meanings to Subic Bay's UCH sites (as shown in Table 3). We also added the prospective ecological function or environmental value of submerged ruins and wrecks as artificial reefs as seen in other case studies abroad (e.g., Simon et al. 2013; Bianchini and Ragonese 2011; Arena et al. 2007).

Table 3: Potential UCH values and stakeholders in Subic Bay based on King et al. (2019)

\begin{tabular}{|c|c|c|}
\hline $\begin{array}{l}\text { Classified heritage } \\
\text { significance }\end{array}$ & Stakeholders & $\begin{array}{l}\text { Possible motivation for } \\
\text { protection and preservation }\end{array}$ \\
\hline Economic value & $\begin{array}{l}\text { Subic Bay dive operators, } \\
\text { local government }\end{array}$ & $\begin{array}{l}\text { Popular tourist destination of } \\
\text { diving }\end{array}$ \\
\hline Social value & Recreational divers & $\begin{array}{l}\text { Sports and recreational diving } \\
\text { sites and spaces }\end{array}$ \\
\hline $\begin{array}{l}\text { Scientific, research or } \\
\text { historical value }\end{array}$ & $\begin{array}{l}\text { NMP, archaeologists, } \\
\text { historians, educators }\end{array}$ & $\begin{array}{l}\text { Data obtained from the } \\
\text { historical narratives and } \\
\text { wreck material culture }\end{array}$ \\
\hline Public education value & $\begin{array}{l}\text { NMP, local government and } \\
\text { schools, cultural heritage } \\
\text { specialists, archaeologists }\end{array}$ & $\begin{array}{l}\text { Courses, exhibition, and } \\
\text { museum development }\end{array}$ \\
\hline Spiritual value & War veterans, locals & $\begin{array}{l}\text { Sacred and grave sites of war } \\
\text { victims }\end{array}$ \\
\hline $\begin{array}{l}\text { Symbolic or } \\
\text { commemorative value }\end{array}$ & Local government, locals & Local identity and history \\
\hline Political value & $\begin{array}{l}\text { National and international } \\
\text { governments }\end{array}$ & $\begin{array}{l}\text { Shared heritage between } \\
\text { governments based on the } \\
\text { country of origin of the wrecks } \\
\text { and the story of surviving } \\
\text { artefacts; peace and solidarity }\end{array}$ \\
\hline $\begin{array}{l}\text { Environmental or } \\
\text { functional value }\end{array}$ & $\begin{array}{l}\text { Local government, } \\
\text { environmental groups, } \\
\text { local fishermen }\end{array}$ & Artificial reefs \\
\hline
\end{tabular}


Schueckler (2018) in his thesis commended on the applicability of the valuescentered theory as "various stakeholders, regardless of whether or not they are included in the process will have something to say, and if not included, often fight to be heard through disruption and obstruction of the process" (p. 11). By assessing heritage values, community perspectives and needs are considered as they may also elicit participatory action towards $\mathrm{UCH}$ protection. In a way, determining heritage values and other stakeholders also challenges the traditional notion that heritage experts are the only authority in caring for and interpreting a site or material (see Avrami et al. 2019; Ronquillo 1992).

\section{BALANCING THE USE AND MANAGEMENT OF UCH}

The reorganisation of MUCHD underscores the necessary adjustment to widen the theory and practice of underwater archaeology as seen in the evidence of long-term maritime tradition in the Philippines (e.g., Robles 2020; King and Orillaneda 2019; Neri 2019; Jago-on and Orillaneda 2019; Ingicco et al. 2018; Lacsina 2016; Mijares et al. 2010; Bolunia and Hontiveros 2009; Noche and Cruz 2005; Dizon 2003; Schaffer 1996). As a division that receives increased government funding being a newly installed office, the MUCHD would hopefully open and develop research and extension works that explore non-conventional set-ups covering emerging perspectives on maritime heritage. Regardless of the setting where archaeological materials were found, its data has indeed provided an understanding of communities as a "result of prehistoric, protohistoric and historic events that occurred in the archipelago" (Ronquillo 1998: 127). But thinking beyond underwater and shipwrecks and placing them in a holistic maritime heritage conversation is essential because it widens the reach and elevates its relevance to other stakeholders beyond its research value, as outlined in the next section.

\section{Connecting People and Practice}

Archaeology has often dealt with issues beyond the straightforward recovery of artefacts. For some, it is necessary to provide continuing technical conservation and protection support so that archaeologists may also continue their research (see Green 2004; Renfrew and Bahn 1996). For other archaeologists, the significance of material remains beyond the academe is more apparent when they have multiple roles to play, such as museum and government officials. In valuing the scientific importance of material remains, 
archaeologists also realise how disconnected they appear to the public and the necessary move to be relevant in other people's work or priorities by engaging non-archaeologists (Acabado and Martin 2020; Jameson 2019; Acabado, Martin and Datar 2017; Bersales 2016; Mijares 1997). Given the lack of practitioners in the Philippines, this is also a strategic way to elicit collaborative roles and solicit support from different stakeholders, given varied expertise and interests.

Besides research, advocacy and local education initiatives can also be regarded as vital components of archaeological campaigns. Without them, numerous negotiations with collaborators and local stakeholders would not have been possible to meet the basic requirements of underwater archaeological activities. Various stakeholders enable heritage interpretation in different forms (e.g., Balangay Voyage ${ }^{54}$; Concerned Citizens for the National Museum Inc. 1993) that enhance the appreciation of the nation's past. Local heritage advocates are also strong allies in protecting $\mathrm{UCH}$ (e.g., Firme and Bautista 2008). These components are also visible during the development of UCH-related policy guidelines and agreements made in the last four decades that address the need to balance varying interests of primary stakeholders.

In considering these examples, addressing the concerns on funding, workforce, education, policy, and their enforcement can be distributed to a broader audience instead of relying only on a single authority, institution, or archaeologist. Moving beyond the focus of preserving or retrieving material evidence and looking at the role of other community members in the consideration of other value ascriptions to a heritage resource can enable participation and shared responsibility (see Manders et al. 2012; Claesson 2011).

\section{Stewardship and Collective Responsibility}

The Philippines' commitment to achieving the United Nations (UN) 2030 Agenda for Sustainable Development Goals (SDG) puts a premium on inclusivity and stakeholder engagement ${ }^{6}$ through the Philippine Development Plan (PDP) 2017-2022.7 The PDP recognises that "culture has several dimensions; its role in development spans and intersects with multiple sectors" (PDP 2017-2022: 95). This can be demonstrated by learning from the UCH policies and practices in other countries, seeking dialogue and partnerships, and strengthening educational, socio-cultural, and economic programmes for the local community in spite of the extensive 
coordination and complex processes involved (see Pearson 2019; Flecker 2017b; Claesson 2011; UNESCO 2011). Specific examples may include revisiting the 2001 UNESCO Convention as political timing and limited resources immobilised its ratification in the Philippines (Orillaneda and Ronquillo 2011). Collaborations with other disciplines (e.g., Anthropology, History, Environment Conservation, and Ocean Sciences) and other groups (e.g., diving community, tourism industry) with parallel mandates or interests are opportunities for improved stakeholder engagement. Strengthening local heritage groups and academic institutions is also an entry point in reinforcing policies and programmes that may benefit both nature and culture.

The challenge posed, however, is when the law and state enforcement do not reflect what is happening on the ground or are misaligned with bureaucratic changes and community values. This can be seen in treasure hunting, which severely impacts the archaeological practice and the discipline's overall heritage significance (see Estrella 2018; Bersales 2016). Its legalisation, even when regulated, conflicts with the national mandate to protect cultural resources where treasure hunting only serves a few profitoriented people. When a site is plundered, there is no guarantee of ownership management of materials that are thought to belong to the state or perhaps ascribed to a cultural group because they are inaccessible. Therefore, treasure hunting negates the fundamental principle enshrined in the constitution that heritage should serve the public interest (Philippine Constitution, Art. II, 1987) and about the state ownership of cultural properties (R.A. No. 10066: Sec. 30). This is reflected in all the reports of treasure-hunted underwater sites in the Philippines, where one cannot trace the context and whereabouts of artefacts. When these properties are lost, their value to the people and future generations remains unknown.

Furthermore, local legislation is still not enough to address treasure hunting since, largely, poverty and corruption are not addressed (BarrettoTesoro 2000; Mijares 1997). Estrella (2018: 27-28) points out the need for community empowerment by ending stereotypes about treasure hunters since they are also being exploited and abused by their financiers due to limited resources and/or options. People advocating against treasure hunting can learn from environmental conservation strategies against wildlife poaching and animal trade. Besides long-term educational campaigns (e.g., van der Ploeg et al. 2011), citizen science (e.g., Araujo et al. 2020; McKinley et al. 2017) and making data more accessible for appropriate public action (e.g., Sullivan et al. 2017), alternative livelihood programmes are one of the key initiatives employed to reduce environmental crimes in 
the Philippines (see Posa et al. 2008). Rather than emphasising ownership of resources, these strategies reflect the importance of stewardship, sustainability, and participation by civil society members in managing environmental resources.

Archaeological tourism is also a promising industry that may play a significant role in UCH protection and management (see Cayron 2017; Medrana 2011). Tourism provides employment and livelihood opportunities that may be an alternative to treasure hunting. However, archaeological tourism's applicability for UCH would need careful planning because the general dive tourism industry also causes pillage and destruction of underwater cultural materials, whether intentionally or otherwise (Orillaneda and Ronquillo 2011). Therefore, tourism can also be a threat if not managed properly. The shipwrecks and wreck sites in Subic Bay (see King et al. 2019) and Calamianes Group of Islands (see Fabinyi 2008) are good candidates to develop archaeological tourism programmes founded on $\mathrm{UCH}$ education and protection since the dive community and local officials are already promoting these $\mathrm{UCH}$ sites, albeit without clearly defined conservation management plans.

In several long-term terrestrial archaeological projects, educational projects and local livelihood opportunities have also emerged. Established programmes or institutions in Ifugao (Acabado and Martin 2020; Dulnuan and Ledesma 2020; Yakal et al. 2020a; Acabado et al. 2017; Martin and Acabado 2015), Kalinga (Yakal et al. 2020b), and Palawan (De Castro 2020; Paz et al. 2017, 2010; Burke Museum 2013 ${ }^{8}$ ) are just some examples in the Philippines that enable stakeholder participation; in this way, community members can co-create public knowledge and are included in the protection of cultural materials.

These examples show that regulating treasure hunting and partnering with financial sponsors may not necessarily be the only strategies for $\mathrm{UCH}$ conservation management in the Philippines. More so, if the Philippines were to seriously push for the adoption of the 2001 UNESCO Convention, the treasure hunting provisions in the law should be abolished. The Philippines must adhere to the Convention's general principles, specifically Rule 2, which states that "commercial exploitation of UCH for trade or speculation or its irretrievable dispersal is fundamentally incompatible with the protection and proper management of underwater cultural heritage. UCH shall not be traded, sold, bought, or bartered as commercial goods" (Manual for Activities directed at Underwater Cultural Heritage 2013: 29). Stewardship and sustainability concepts adhere to the 2001 UNESCO Convention, which 
emphasises collective responsibility in safeguarding cultural heritage, rather than ownership by individuals or the privileged few (see Merrill 2003). Primarily committing to this principle may further facilitate the realisation of the abovementioned examined strategies and examples.

\section{CONCLUSION}

The birth of the UAU was a response to unsystematic shipwreck investigations by inexperienced staff and groups in the earlier decades. Although the passage of R.A.'s 4846, 10066 and 11333 recognised the need to protect and preserve the country's cultural properties, there is still a need to highlight the importance and vulnerabilities of archaeological heritage resources. With the reorganisation of the NMP and the transfer of regulatory powers to NCCA, there is also a need to review laws and strengthen policy enforcement and education activities. Archaeological data must be interpreted and integrated into school curriculums and cultural heritage programmes led by the government. ${ }^{9}$ These challenges also provide possibilities to co-develop the discipline through joint efforts with mainstream institutions (e.g., NMP, LGU, ASP), collaborators (e.g., diving community), and regional organisations (e.g., SEAMEO-SPAFA, NGS) that share common ideals towards the protection of $\mathrm{UCH}$ and nature as well as cultural wellbeing.

This article builds on the premise of the urgent need to safeguard UCH. For starters, "effective resource management requires reliable data on which to base preservation and conservation priorities" (Satchell and Palma 2007: 3). The reliability of data also depends on how authorities or even researchers manage the internal and external factors of a project. Engaging the stakeholders is a proven practice that enables both negative and positive outcomes based on different investment levels or layers of involvement in a UCH project. Though it would take time, testing, and tools, practitioners should assess the applicability of the values-led theory and people-centred model in managing $\mathrm{UCH}$ in the Philippines. Given the varying motivations and value ascriptions between stakeholders to $\mathrm{UCH}$, there is a need to set the terms of involvement (Poulios 2010), to understand the limitations, and recognise the disconnect between aims and practice (Avrami and Mason 2019). There are also considerations of power relations amongst stakeholders and authorities or specialists when applying this approach in conservation management practice. At times, conflicts between 
stakeholders as well as deeper political complexities have also emerged (Avrami and Mason 2019; Poulios 2010). There is also a tendency to focus on the preservation of cultural materials even if this approach equally advocates the importance of the intangible elements of heritage (Poulios 2010).

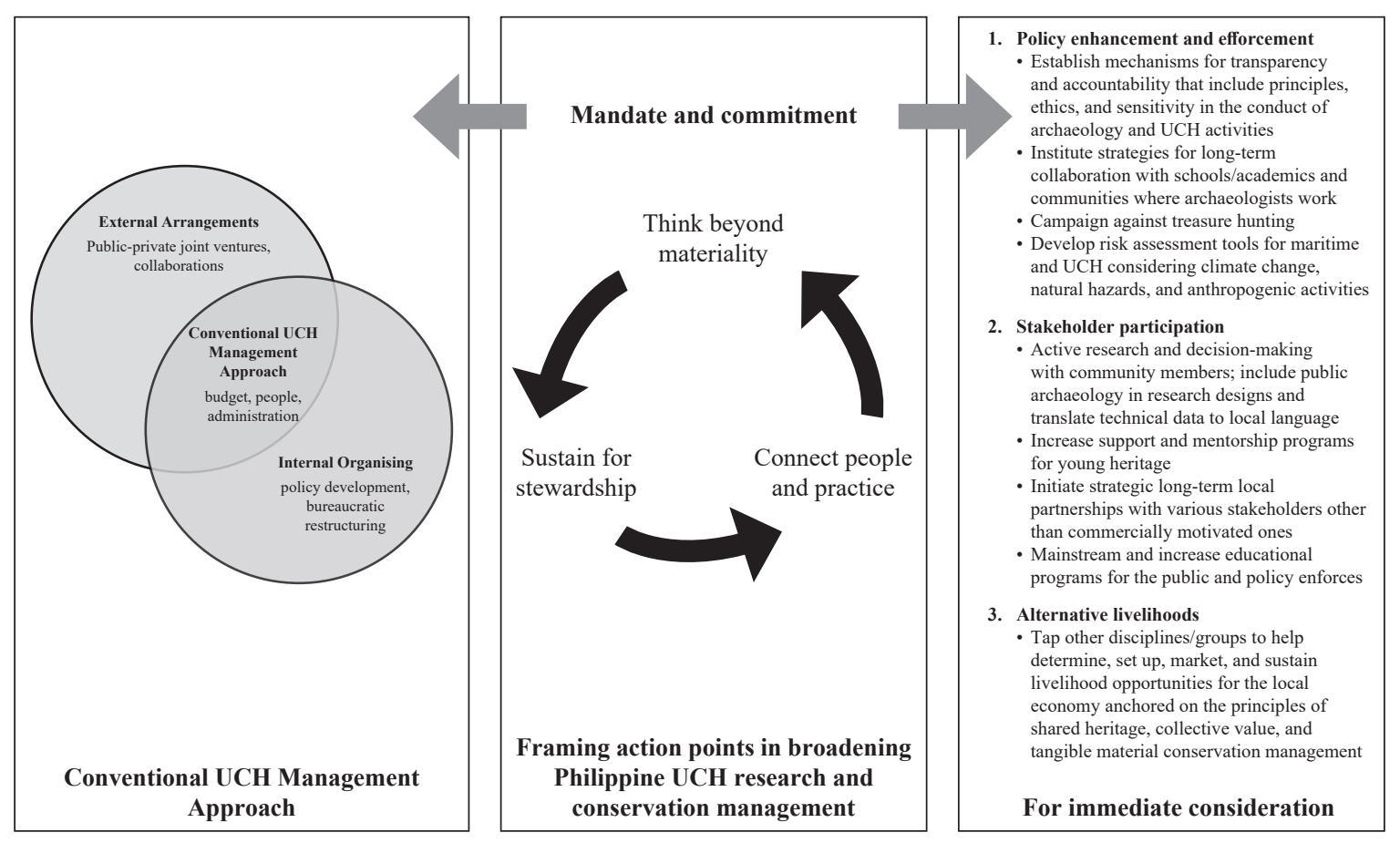

Figure 7: Synthesis of recommendations and their relationship with the proposed action points and the conventional approach in managing UCH in the Philippines (Diagram patterned in the risk management: Principles and guidelines of ISO, https://www.iso.org/obp/ui/\#iso:std:iso:31000:ed-1:v1:en).

For Philippine UCH, the following are among the immediate considerations, especially in communities with established treasure hunting and illicit trading systems: enhancing and enforcing policies, applying sustainable development strategies that connect stewardship for both people and the sea, and developing alternative livelihood programmes (as shown in Figure 7). These recommendations reflect the need for the application of the values-led theory and a people-centred model to conservation management which in a way have long been advocated locally through the emphasis on stakeholder education and involvement. By examining community needs and what archaeological research means or may be of value to people (see Acabado et al. 2017; Cayron 2017; Lising 2016; Acabado and Lauer 2014; Medrana 2011; Mijares 1997; Ronquillo 1992) and simultaneously complementing this by strengthening localised 
public education initiatives (e.g., Acabado and Martin 2020; De Castro 2020; Yakal et al. 2020a, 2020b; Dulnuan and Ledesma 2020; Kintanar and Barretto-Tesoro 2020), a values-led and people-centred approach to conservation management may better facilitate the full realisation of maritime heritage significance in the Philippines across generations.

\section{ACKNOWLEDGEMENTS}

We would like to acknowledge the following institutions for their continued research guidance and support: Maritime and Underwater Cultural Heritage and Archaeology Divisions, National Museum of the Philippines; Archaeological Studies Program, University of the Philippines Diliman; Regional Centre for Archaeology and Fine Arts; Southeast Asian Ministers of Education Organization (SEAMEO) and the Lisa Maskell Fellowships, Gerda Henkel Foundation. We would also like to thank Chihiro Nishikawa, Dr. Eusebio Dizon, Emil Robles, Professor Dr. Wiebke Bebermeier, Professor Dr. Christopher Miller, Dr. Armand Mijares, Atty. Lucille Malilong-Isberto, Atty. Kathleen Tantuico, Dr. Lee Anthony Neri, Dr. Noel Hidalgo Tan, Dr. Ligaya Lacsina, Sheldon Clyde Jago-on, Rachelle Anne Ureta, Emil Bersamira, Marlon Texon, Anna Pineda, Ed Bersamira and Fung $\mathrm{Yu}$ for providing advice, additional information, and technical assistance. We are also grateful for the editor and two anonymous reviewers who provided constructive feedback which strengthened this article. Lastly, we would like to honour our colleague Sheldon Clyde Jago-on (17th September 1971-9th March 2021) who was instrumental and dedicated his life to public service through the development of Philippine archaeology: we miss you.

\section{NOTES}

* Kristine Kate A. Lim is a Lisa Maskell Fellow and a doctoral candidate at the Institute of Geographical Sciences, Department of Earth Sciences, Freie Universitat Berlin. She holds a BA in Political Science from De La Salle University and a MA in Archaeology from University of the Philippines. Her ongoing research examines the risks and vulnerabilities of Philippine maritime cultural landscapes, given the natural hazards, climate change and human activities. Kate is a field archaeologist and a development worker with extensive experience in working for non-profit organisations and the public sector. Currently, she sits as a board member of several heritage groups such as the Kapisanan ng mga Arkeologist sa Pilipinas, Inc. (Guild of Archaeologists in the 
Philippines), Tuklas (Discover) Pilipinas Society, and Artists' Welfare Project, Inc. She is also the current Emerging Professional Working Group (EPWG) representative of ICOMOS Philippines and a member of the International Committee on Archaeological Heritage Management (ICOMOS-ICAHM).

** Bobby C. Orillaneda is the Officer-in-Charge and Senior Museum Researcher at the Maritime and Underwater Cultural Heritage Division of the National Museum of the Philippines. He is currently finishing his doctoral degree at the Centre for Maritime Archaeology (OCMA), University of Oxford in England. He has extensive experience in shipwreck exploration and excavation projects in the Philippines, Thailand, Indonesia, Sri Lanka and Egypt. He is also part of a training team that carries out maritime archaeology capacity-building programmes in Taiwan, Thailand and Indonesia. He has published several book chapters, conference papers and journal articles. Bobby is the current President of the Kapisanan ng mga Arkeologist sa Pilipinas, Inc. (Guild of Archaeologists in the Philippines) and a member of ICOMOS Philippines and the International Committee on Underwater Cultural Heritage Management (ICOMOSICUCH). His interests include Asian ceramics, Southeast Asian pre-colonial and colonial maritime trade, World War II shipwrecks and the management of the Philippine Underwater Cultural Heritage.

*** Catherine May P. King is a Lisa Maskell Fellow presently pursuing her doctorate degree in Archaeology at the Institute for Scientific Archaeology at Tübingen University, Germany. She was a former Senior Museum Researcher at the Maritime and Underwater Cultural Heritage Division of the National Museum of the Philippines. She has participated in many training courses, archaeological explorations, excavations both on land and underwater locally and internationally, including Cambodia, France, Australia, and Croatia. Her current research focuses on early maritime trade and history of the Philippines. She is also interested and involved in the practice of Public Archaeology in the Philippines.

1 A notice to the public was posted on 28th December 2020 entitled "Assumption by the National Commission for Culture and the Arts of Certain Regulatory Functions Formerly Carried Out by the National Museum of the Philippines". See https://www. facebook.com/NCCAOfficial/posts/10158265490365283 (accessed 9 January 2021).

2 The ASP brochure and programme descriptions and courses can be accessed at this link: http://asp.upd.edu.ph/ (accessed 9 August 2020).

3 An example of the NMP's online presence consists of "\#MaritimeMonday", featuring different shipwrecks and archaeological objects like this post about a shipwreck found off the coast of Pandanan Island, Palawan: https:/www.facebook.com/ nationalmuseumofthephilippines/posts/3521198064571153 (accessed 9 January 2021).

4 The University of Santo Tomas Graduate School-Center for Conservation of Cultural Property and Environment in the Tropics (USTGS-CCPET) was established in 2003 and offers a master's degree in Cultural Heritage Studies. These are further links to the programme: http://www.ust.edu.ph/academics/programs/master-of-arts-in-culturalheritage-studies/ and http:/graduateschool.ust.edu.ph/center-for-conservation-ofcultural-property-and-environment-in-the-tropics/ccpet-about-us/ (accessed 9 January 2021). 
5 The Balangay Voyage is an educational expedition conducted by the Kaya ng Pinoy, Inc. that traces the routes of Filipino ancestors using replicas of the balangay. A documentary was premiered at CineMalaya in 2014 about this voyage: "Voyage of the Balangay directed by Minda Monica Ponce-Rodriguez," YouTube Channel of Fung Yu, 19 September 2017. https://www.youtube.com/watch?v=pGmQW5oalyo $\& \mathrm{t}=280$ s (accessed 9 January 2021).

6 The Philippines' voluntary national review 2019 of SDG implementation. https://sustainabledevelopment.un.org/memberstates/philippines (accessed 9 January 2021).

7 The Philippine Development Plan 2017-2022. Downloaded at http://pdp.neda.gov .ph/ (accessed 9 January 2021).

8 The "Ancient Shores, Changing Tides" initiated by the Burke Museum in 2013 project aims to connect communities in Suquamish, Washington, USA, and El Nido, Palawan, Philippines through collaborative activities and exhibitions. https://ancientshoreschangingtides.wordpress.com/about/ (accessed 09 January 2021).

9 The promulgation of the R.A. 9155, also known as "An Act Instituting a Framework of Governance for Basic Education, Establishing Authority and Accountability, Renaming the Department of Education, Culture and Sports (DECS) as a Department of Education (DepEd)", instituted cultural education as an integral part of basic education while its supervision was transferred to the NCCA. http://gwhs-stg02.i.gov .ph/ s2govnccaph/philippine-cultural-education-program-pcep/ (accessed 9 January 2021). Moreover, the R.A. 10066 mandates all cultural agencies and LGUs to maintain an inventory under their jurisdiction which will be registered in the PRECUP as its repository database. This registry can be accessed at this link: http://gwhs-stg02 .i.gov.ph/ $\sim \mathrm{s} 2$ govnccaph/philippine-registry-cultural-property-precup/. In connection, the NCCA established the Cultural Mapping Program to help LGUs identify and account for their cultural properties. See http:/gwhs-stg02.i.gov.ph/ s2govnccaph/ about-ncca-3/cultural-mapping-program/ (accessed 9 January 2021).

\section{REFERENCES}

Acabado, S. and Lauer, A. 2014. Rethinking history, conserving heritage: Archaeology and community engagement in Ifugao, Philippines. The SAA Archaeological Record 14 (5): $12-17$.

Acabado, S. and Martin, M. 2020. Decolonizing the past, empowering the future: Community-led heritage conservation in Ifugao, Philippines. Journal of Community Archaeology and Heritage 7 (3): 171-186. https://doi.org/10.1080/20518196.2020 .1767383

Acabado, S., Martin, M. and Datar, F. 2017. Ifugao archaeology: Collaborative and indigenous archaeology in the Northern Philippines. Advances in Archaeological Practice 5: 1-11. https://doi.org/10.1017/aap.2016.7

Alba, L. A. 1984. The genesis of underwater archaeology in the Philippines. Unpublished report, National Museum, Manila. 
1990. Preliminary report on the 1989 Marinduque underwater archaeology project. Unpublished report, National Museum, Manila.

Angeles, J. A. 2007. The Battle of Mactan and the indigenous discourse on war. Philippine Studies 55: 3-52.

Araoz, G. F. 2011. Preserving heritage places under a new paradigm. Journal of Cultural Heritage Management and Sustainable Development 1: 55-60. https://doi.org/10 $.1108 / 20441261111129933$

Araujo, G. et al. 2020. Getting the most out of citizen science for endangered species such as whale shark. Journal of Fish Biology 96: 864-867. https://doi.org/10.1111/ jfb. 14254

Arena, P. T., Jordan, L. K. B. and Spieler, R. E. 2007. Fish assemblages on sunken vessels and natural reefs in southeast Florida, USA. In Biodiversity in enclosed seas and artificial marine habitats, eds. Relini, G. and Ryland, J., Vol. 193. Dordrecht, Netherlands: Springer.

Argyropoulos, V. and Stratigea, A. 2019. Sustainable management of underwater cultural heritage: The route from discovery to engagement; Open issues in the Mediterranean. Heritage 2: 1588-1613. https://doi.org/10.3390/heritage2020098

Avrami E., Mason, R. and de la Torre, M. 2000. Values and heritage conservation: Research report. Los Angeles, CA: The Getty Conservation Institute. https://www.getty .edu/conservation/publications_resources/pdf_publications/pdf/valuesrpt.pdf (accessed 9 August 2020).

Avrami, E. and Mason, R. 2019. Mapping the issues of values. In Values in heritage management: Emerging approaches and research directions, eds. Avrami, E., Macdonald, S., Mason, R. and Meyers, D., 9-33, Los Angeles, CA: The Getty Conservation Institute. https:/www.getty.edu/publications/heritagemanagement/ downloads/Avrami_etal_ValuesinHeritageManagement.pdf (accessed 9 January 2021).

Avrami, E. et al. 2019. Values in heritage management: Emerging approaches and research directions. Los Angeles, CA: The Getty Conservation Institute. https://www.getty. edu/publications/heritagemanagement/ (accessed 9 August 2020).

Barretto-Tesoro, G. 2000. Muni-Muni. Hukay Journal 2: 64.

Batoon, L. 2005. Jolo shipwreck investigation (February 14-19, 2005). Unpublished report, National Museum, Manila.

Bergreen, L. 2003. Over the edge of the world: Magellan's terrifying circumnavigation of the globe. New York: William Morrow/Harper Collins.

Bersales, J. E. R. 2016. Looking for Yamashita's gold. Philippine Quarterly of Culture and Society 44 (3/4): 183-210.

Bianchini, M. and Ragonese, S. 2011. The potential importance of shipwrecks for the fisheries, the environment and the touristic fruition. In Marine research at CNR, eds. Brugnoli, E., Cavarretta, G., Mazzola, S., Trincardi, F., Ravaioli, M. and Santoleri, R., 1923-1939. Rome, Italy: National Research Council of Italy, Department of Earth and Environment.

Bolunia, M. J. L. A. and Hontiveros, G. 2009. Harbour archaeology: Studies of Philippine ancient ports and harbours. MINDAyawan Journal of Culture and Society 1 (1): 1-12. https://doi.org/10.3860/minda.v1i1.1244 
Bourque, B. J. et al. 1980. Conservation in archaeology: Moving toward close cooperation. American Antiquity 45 (4): 794-799.

Burke Museum. 2013. Ancient shores, changing tides. https://ancientshoreschangingtides. wordpress.com/about/ (accessed 9 January 2021).

Calderon, M. J. 1989. Underwater archaeology in the Philippines. Philippine Quarterly of Culture and Society 17: 322-325.

Capili, E. B., Ibay, A. C. S. and Villarin, J. R. 2005. Climate change impacts and adaptation on Philippine coasts. OCEANS 2005 MTS/IEEE 3: 2299-2306.

Cayron, J. G. 2017. Archaeological heritage tourism in the Philippines: Challenges and prospects. In Collision or collaboration: Archaeology encounters economic development, eds. Gould, P. G. and Pyburn, K. A., 89-102. Cham: Springer International Publishing. https://doi.org/10.1007/978-3-319-44515-1_7

Claesson, S. 2011. The valueand valuation ofmaritime culturalheritage.InternationalJournal on Cultural Property 18: 61-80. https://doi.org/10.1017/S0940739111000051

Concerned Citizens for the National Museum, Inc. 1993. Saga of the San Diego. Manila: Vera-Reyes.

Conese, E. T. and Nicolas, N. 1984. A report on the survey and exploration of shipwreck site in coastal waters of Barotac Viejo, Iloilo (March 1-30, 1984). Unpublished report, National Museum, Manila.

Conese, E. T., Aromin, F. Jr., Palpal-Latoc, V. and De Celis, A. K. 1981. Report on marine archaeological exploration conducted in Gaspar Island, Marinduque Province. Unpublished report, National Museum, Manila.

Conese, M. E. T. 1989. Underwater archaeology in the Philippines. Unpublished report, National Museum, Manila.

Court, S. and Wijesuriya, G. 2015. People-centered approaches to the conservation of cultural heritage: Living heritage. Italy: ICCROM.

Cuevas, M. A. 1993. Pandanan Island underwater archaeology project: Inspection of a reported site. Unpublished report, National Museum, Manila.

De Castro, L. 2020. Placemaking: Assessing the impact of archaeology in the Dewil Valley. Master's diss., University of the Philippines, Philippines.

de la Torre, M. 2002. Assessing the values of cultural heritage: Research report. Los Angeles, CA: The Getty Conservation Institute. https://www.getty.edu/ conservation/publications_resources/pdf_publications/values_cultural_heritage .html (accessed 9 August 20020).

de la Torre, M. and Mason, R. 1999. Economics and heritage conservation: A meeting organized by the Getty Conservation Institute, December 1998. Los Angeles, CA: The Getty Conservation Institute. https:/www.getty.edu/conservation/ publications_resources/pdf_publications/economics_and_heritage.html (accessed 9 August $20 \overline{2} 0$ ).

2002. Introduction. In Assessing the values of cultural heritage research report, 3-4. Los Angeles, CA: The Getty Conservation Institute.

Díaz-Andreu, M. 2017. Heritage values and the public. Journal of Community Archaeology and Heritage 4: 2-6. https://doi.org/10.1080/20518196.2016.1228213

Dizon, E. Z. 1992. Status of underwater archaeological researches in the Philippines 1989-91: Prospect for 1992. Bulletin of the Australian Institute for Maritime Archaeology 16 (1): 41-47. 
2003. Underwater and maritime archaeology in the Philippines. Philippine Quarterly of Culture and Society 31: 1-25.

Dulnuan, J. H. and Ledesma, C. P. 2020. Archaeology in the classroom: A perspective from Kiangan, Ifugao, Philippines (Arkiyoloji sa silid-aralan: Isang pananaw mula sa Kiangan, Ifugao). SPAFA Journal 4 [Online]. https://doi.org/10.26721/ spafajournal.v4i0.613

Estrella, V. P. 2018. Illicit trade in gold cultural materials in Butuan, Philippines. Kasarinlan: Philippine Journal of Third World Studies 33 (2): 1-34.

Fabinyi, M. 2008. Dive tourism, fishing, and marine protected areas in the Calamianes Islands, Philippines. Marine Policy 32 (6): 898-904. https://doi.org/10.1016/ j.marpol.2008.01.004

Firme, E. P. and Bautista G. G. 2008. Accomplishment report of the field investigation and coordination with local/provincial officials by the representatives of the National Museum on the reported shipwreck off the coast of San Juan, Batangas (July 23-24, 2008). Unpublished report, National Museum, Manila.

Flecker, M. 2017a. Early Chinese voyaging in the South China Sea: Implications on territorial claims. Journal of Maritime Studies and National Integration 1 (1): 1-21. https://doi.org/10.14710/jmsni.v1i1.1367

2017b. Legislation on underwater cultural heritage in Southeast Asia: Evolution and outcomes. Singapore: TRENDS-ISEAS-Yusof Ishak Institute. https://doi.org/ $10.1355 / 9789814818063$

Fredheim, L. H. and Khalaf, M. 2016. The significance of values: Heritage value typologies re-examined. International Journal of Heritage Studies 22: 466-481. https://doi.org/10.1080/13527258.2016.1171247

Frigerio, A. 2013. The underwater cultural heritage: A comparative analysis of international perspectives, laws and methods of management. $\mathrm{PhD}$ diss., IMT Institute for Advanced Studies, USA. http://e-theses.imtlucca.it/107/

Goddio, F. 1996. The treasures of San Diego. New York and Paris: Association Française d'Action Artistique, Fondation Elf, and Elf Aquitaine International Foundation, Inc.

Goddio, F. et al. 2002. Lost at sea: The strange route of the Lena Shoal junk. London: Periplus Publishing London, Ltd.

Green, J. N. 2004. Maritime archaeology: A technical handbook (2nd ed.). San Diego, CA: Elsevier Academic Press.

Hamilton, D. L. 1999. Conservation of cultural materials from underwater sites. Archives and Museum Informatics 13: 291-323. https://doi.org/10.1023/A:1012420510516

ICOMOS Japan. 2004. Nara + 20: On heritage practices, cultural values, and the concept of authenticity. http://www.japan-icomos.org/pdf/nara20_final_eng.pdf (accessed 9 August 2020).

ICOMOS. 1974. The Venice charter: International charter for the conservation and restoration of monuments and sites. https://www.icomos.org/charters/venice_e.pdf (accessed 9 August 2020).

2011. Guidance on heritage impact assessments for cultural world heritage properties. https://www.iccrom.org/sites/default/files/2018-07/icomos_guidance_ on_heritage_impact_assessments_for_cultural_world_heritage_properties.pdf (accessed 9 August 2020). 
2013. The Burra charter: The Australia icomos charter for places of cultural significance. http://australia.icomos.org/publications/charters (accessed 9 August 2020).

Ingicco, T. et al. 2018. Earliest known hominin activity in the Philippines by 709 thousand years ago. Nature 557: 233-237. https://doi.org/10.1038/s41586-018-0072-8

Jago-on, S. C. B. and Bersamira, E. 2018. Brief report on the coordination and information dissemination to LGUs on the underwater archaeological explorations in the Visayan Sea, Guimaras Strait, and Cuyo East Pass. Unpublished report, National Museum, Manila.

Jago-on, S. C. B. and Orillaneda, B. C. 2016. The Catanauan underwater archaeological project: 2016 progress report. Unpublished report, National Museum, Manila. 2019. Archaeological researches on the Manila Galleon Wrecks in the Philippines. In Archaeology of Manila Galleon Seaports and early maritime globalization. The Archaeology of Asia-Pacific navigation, eds. Wu, C., Junco Sanchez, R. and Liu, M., Vol. 2. Singapore: Springer. https://doi.org/10.1007/978-981-32-9248-2_7

Jago-on, S. C. B. et al. 2014. Brief report on the underwater archaeological excavation of wreck in Laylay, Boac, Marinduque. Unpublished report, National Museum, Manila.

Jameson, J. H. 2019. Introduction: The critical junctures of archaeology, heritage, and communities. In Transforming heritage practice in the 21st century: Contributions from community archaeology, eds. Jameson, J. H. and Musteaţă, S., 1-12. Cham: Springer International Publishing. https://doi.org/10.1007/978-3-030 $-14327-5$

Jing, Y. and Li, J. 2019. Who owns underwater cultural heritage in the South China Sea. Coastal Management 47: 107-126. https://doi.org/10.1080/08920753.2019 .1540908

Jocano, F. L. 1975. The Philippines at Spanish contact. Manila: MCS Enterprises.

King, C. P. 2018a. Activity report: Heritage month activity. Unpublished report, National Museum of the Philippines, Manila.

2018b. Activity report: MUCH forum. Unpublished report, National Museum of the Philippines, Manila.

2019. Activity report: Heritage month activity. Unpublished report, National Museum of the Philippines, Manila.

King, C. P. and Orillaneda, B. C. 2019. Reassessing 13th-century Sino-Southeast Asian trade relations. Paper presented at the 3rd SEAMEO-SPAFA International Conference on Southeast Asian Archaeology, Bangkok, Thailand, 17-21 June.

King, C. P., Orillaneda, B., Ureta, R. and Austero, N. 2019. Examining the potential of underwater cultural heritage preservation and management in the Philippines: The Subic Bay shipwrecks. Paper presented at the Proceedings at the International Archaeological Conference, Miri, Sarawak, Malaysia, 24-30 September 2019.

King, C. P., Ureta, R. A. G. P., Austero, N. M. and Orillaneda, B. C. 2018. Preliminary underwater archaeological investigations of the USS Majaba (El Capitan) and the underwater cultural heritage of Subic Bay. Unpublished report, National Museum, Manila. 
Kintanar, A. N. and Barretto-Tesoro, G. 2020. Raising heritage consciousness in Pinagbayanan, San Juan, Batangas, Philippines (Ang pagtaguyod ng kaalaman tungkol sa pamanang lahi sa bayan ng San Juan, Batangas). SPAFA Journal 4 [Online]. https://doi.org/10.26721/spafajournal.v4i0.612

Lacsina, L. 2016. Examining pre-colonial Southeast Asian boatbuilding: An archaeological study of the Butuan Boats and the use of edge-joined planking in local and regional construction techniques. $\mathrm{PhD}$ diss., Flinders University, Australia. https://theses.flinders.edu.au/view/58348c74-8c36-4b2e-a714-ec6fa70d790e/1

Lacsina, L. and Jago-on, S. C. B. 2019. Report on travel to Mindoro and vicinities (February 12-17, 2019). Unpublished report, National Museum, Manila.

Lacsina, L., Orillaneda, B. C. and Bersamira, E. 2017. Field report for travel undertaken in Guiuan, Eastern Samar and vicinities, particularly Sulu-An Island (May 7-15, 2017). Unpublished report, National Museum, Manila.

Lacsina, L. et al. 2011. Report on the third season of the Scarborough Shoal underwater archaeological project (March 12-May 2, 2011). Unpublished report, National Museum, Manila.

Lim, K. A. 2019. An overview of the vulnerabilities of maritime cultural landscapes in the Philippines. Paper presented at the European Association for Southeast Asian Studies (EuroSEAS) 2019, Berlin, Germany, 12 September. https://euroseas2019. org/program/panels/scholars-in-emerging-archaeological-researches-in-thephilippines

Lising, C. M. Q. 2016. A review of the cultural heritage management of the prehistoric cave sites in Peñablanca, Cagayan Province, Philippines. Master's diss., University of the Philippines, Philippines.

Lopez, P. T. Jr. 1967. Marine archaeology in the Philippines. Unpublished report, National Museum, Manila.

Mak, B. 2014. Archaeology of a digitization. Journal of the Association for Information Science and Technology 65 (8): 1515-1526. https://doi.org/10.1002/asi.23061

Malilong, L. K. E. and Villanueva, M. G. E. S. 2017. World heritage and human rights policy and legislation in the Philippines. In World heritage and human rights, ed. Larsen, P. B. London: Routledge. https://doi.org/10.4324/9781315402789-14

Manders, M., Tilburg, H. V. and Staniforth, M. 2012. Unit 6: Significance assessment. In Training manual for the UNESCO foundation course on the protection and management of underwater cultural heritage in Asia and the Pacific, 1-26. Bangkok: Thailand: UNESCO.

Martin, M. and Acabado, S. 2015. Community participation in the Ifugao archaeological project. National Museum Journal of Cultural Heritage 1 (1): 39-45.

Mason, R. 2002. Assessing the values in conservation planning: Methodological issues and choices. In Assessing the values of cultural heritage research report, ed. de la Torre, M., 5-30. Los Angeles, CA: The Getty Conservation Institute. 2006. Theoretical and practical arguments for values-centered preservation. CRM: The Journal of Heritage Stewardship 3 (2): 21-48.

2008. Be interested and beware: Joining economic valuation and heritage conservation. International Journal of Heritage Studies 14: 303-318. https://doi.org/10.1080/13527250802155810 
McKinley, D. C. et al. 2017. Citizen science can improve conservation science, natural resource management, and environmental protection. Biological Conservation 208: 15-28. https://doi.org/10.1016/j.biocon.2016.05.015

Medrana, J. G. L. 2011. Incorporating a tourism agenda in public archaeology work. Hukay Journal 16: 49-63.

Merrill, A. T. 2003. The strategic stewardship of cultural resources: To preserve and protect. New York: Routledge.

Mijares, A. S. B. 1997. The role of the community in the protection of archaeological sites. National Museum Papers 7 (2): 89-99.

Mijares, A. S. et al. 2010. New evidence for a 67,000-year-old human presence at Callao Cave, Luzon, Philippines. Journal of Human Evolution 59: 123-132.

Muckelroy, K. 1978. Maritime archaeology. Cambridge, UK: Cambridge University Press.

National Museum of the Philippines. 2016. QMS manual of the cultural properties regulation division. https://www.nationalmuseum.gov.ph/nationalmuseumbeta/ Transparency/QMS-CPRD\%20Final\%20pdf.pdf (accessed 09 January 2021).

Neri, L. A. M. 2019. Obsidian sourcing and characterization in the Celebes region: An initial interpretation on the "Celebes Seafaring People". Open Archaeology 5: 167-179. https://doi.org/10.1515/opar-2019-0012

Noche, M. and Cruz, S. 2005. Lonely sentinels of the sea: The Spanish lighthouses in the Philippines. Manila: UST Publishing House.

Orillaneda, B. C. 2000. Carasanan underwater archaeological project: A field report. Unpublished report, National Museum, Manila.

. 2012. The Santa Cruz shipwreck excavation: A reflection on the practice of underwater archaeology in the Philippines. In Innovation and adaptation: Marine archaeology in Southeast Asia, ed. Tan, H., 86-102. Singapore: Asian Civilisations Museum.

Orillaneda, B. C. and Jago-on, S. C. B. 2017. Recent updates on Philippine maritime archaeology. Paper presented at the Proceedings of the International Symposium "Past, Present and Future of ASEAN Maritime Heritage", Fine Arts Department, Ministry of Culture, Thailand, 15-16 June.

Orillaneda, B. C. and Ronquillo, W. P. 2011. Protecting and preserving the underwater cultural heritage in the Philippines: A background paper. Paper presented at the Proceedings of the Asia Pacific Regional Conference on Underwater Cultural Heritage, Manila, 8-12 November.

Orillaneda, B. C. and Soriano, A. 2006. Field report on the underwater archaeological survey of Scarborough Shoal. Unpublished report, National Museum, Manila 2010. The Scarborough Shoal underwater archaeological survey field report. Unpublished report, National Museum, Manila.

Patiwael, P. R., Groote, P. and Vanclay, F. 2019. Improving heritage impact assessment: An analytical critique of the ICOMOS guidelines. International Journal of Heritage Studies 25: 333-347. https://doi.org/10.1080/13527258.2018.1477057

Paz, V. et al. 2017. Palawan Island Palaeohistory research project. Archaeological Studies Program Library, University of the Philippines, Quezon City. 2010. Palawan Island Palaeohistory research project. Archaeological Studies Program Library, University of the Philippines, Quezon City. 
Pearson, N. 2019. Protecting and preserving underwater cultural heritage in Southeast Asia. In The Palgrave handbook on art crime, eds. Hufnagel, S. and Chappell, D., 685730. London: Palgrave Macmillan. https://doi.org/10.1057/978-1-137-54405-6_31

Peterson, J. A., Jalandoni, A. and Rocha, C. 2017. An archaeological survey of an underwater cave in Marigondon, Philippines. In The archaeology of underwater caves, ed. Campbell, P., 56. Eastleigh, UK: The Highfield Press Southampton.

Posa, M. R. C. et al. 2008. Hope for threatened tropical biodiversity: Lessons from the Philippines. BioScience 58: 231-240. https://doi.org/10.1641/B580309

Poulios, I. 2010. Moving beyond a values-based approach to heritage conservation. Conservation and Management of Archaeological Sites 12: 170-185. https://doi .org/10.1179/175355210X12792909186539

Renfrew, C. and Bahn, P. 1996. Archaeology: Theories, methods, and practice. London: Thames and Hudson.

Republic of the Philippines. 2010. National Cultural Heritage Act of 2009 [Republic Act No. 10066]. https://www.officialgazette.gov.ph/2010/03/26/republic-act-no-10066/ (accessed 9 August 2020). 2013. Implementing rules and regulations of the Republic Act. No. 10066. https://www.officialgazette.gov.ph/2013/03/07/implementing-rules-and -regulations-of-republic-act-no-10066/ (accessed 9 August 2020).

Robles, E. 2020. Sea levels and the archaeology of Mindoro and Palawan: Implications for Island Southeast Asia. PhD diss., University of the Philippines, Philippines.

Rocha, C., et al. 2017. Paleoenvironmental investigations, chemical analysis and characterization of underwater strata of Marigondon Cave. Quaternary International 431: 223-231. https://doi.org/10.1016/j.quaint.2014.04.005

Rodgers, B. A. 2004. The archaeologist manual for conservation: A guide to non-toxic, minimal intervention artifact stabilization. New York: Kulwer Academic/Plenum Publishers. https://doi.org/10.1007/b110192

Ronquillo, W. 1990. Philippine underwater archaeology: Present research projects and new developments. Bulletin of the Australian Institute for Maritime Archaeology 14 (1): 21-24.

1992. Philippine archaeological heritage disappearing cultural resource. National Museum Papers 3 (2): 61-66.

Ronquillo, W. P. and Dizon, E. Z. 1999. An archaeological resource management manual for the National Museum of the Philippines. National Museum Papers 9 (2): 28-37.

Satchell, J. and Palma P., eds. 2007. Managing the marine cultural heritage: Defining, accessing, and managing the resource. London: Council of British Archaeology.

Schaffer, L. N. 1996. Maritime Southeast Asia to 1500. Armonk, NY: M.E. Sharpe.

Schueckler, E. 2018. Choosing how to remember: Negative heritage and values-centered preservation. Masters diss., University of Pennsylvania, Philadelphia, PA.

Shott, M. 2014. Digitizing archaeology: A subtle revolution in analysis. World Archaeology 46 (1): 1-9. https://doi.org/10.1080/00438243.2013.87904

Simon, T., Joyeux, J.-C. and Pinheiro, H. T. 2013. Fish assemblages on shipwrecks and natural rocky reefs strongly differ in trophic structure. Marine Environmental Research 90: 55-65. https://doi.org/10.1016/j.marenvres.2013.05.012 
Spalding, M. J. 2011. Perverse sea change: Underwater cultural heritage in the ocean is facing chemical and physical changes. Cultural Heritage and Arts Review (Summer) 2 (1): 12-16. https://oceanfdn.org/perverse-sea-change-underwater -cultural-heritage-in-the-ocean-is-facing-chemical-and-physical-changes/ (accessed 9 August 2020).

Sullivan, B. L. et al. 2017. Using open access observational data for conservation action: A case study for birds. Biological Conservation 208: 5-14. https://doi.org/10.1016/ j.biocon.2016.04.031

Tantuico, K. D. 2020. The 2020 re-excavation of Callao Cave, Northeastern Luzon, the Philippines. SPAFA Journal 4 [Online]. https://doi.org/10.26721/spafajournal.v4i0 .638

UNESCO. 2011. Convention on the protection of the underwater cultural heritage and its context. http://www.unesco.org/new/en/culture/themes/underwater-culturalheritage/underwater-cultural-heritage/definition-of-underwater-cultural-heritage/ (accessed 9 August 2020).

2013. Manual for activities directed at underwater cultural heritage: Guidelines to the annex of the UNESCO 2001 convention. http://www.unesco.org/culture/en/ underwater/pdf/UCH-Manual.pdf (accessed 9 August 2020).

Ureta, R. 2019. Activity report: Heritage month activity. Unpublished report, National Museum, Manila.

Ureta, R. A. G. P. et al. 2019. R/V Petrel's survey activities in Philippine waters (April 6-May 9, 2019). Unpublished report, National Museum, Manila.

van der Ploeg, J. et al. 2011. Assessing the effectiveness of environmental education: Mobilizing public support for Philippine crocodile conservation. Conservation Letters 4: 313-323. https://doi.org/10.1111/j.1755-263X.2011.00181.X

Villarin, J. T. et al. 2016. 2016 Philippine Climate Change Assessment (PhilCCA): The physical science basis. Phillipines: The Oscar M. Lopez Center for Climate Change Adaptation and Disaster Risk Management Foundation Inc. and Climate Change Commission.

Vladimirova, M. 2016. Maritime cultural landscape: Cultural tourism; Sustainable development. International Journal of Cultural and Digital Tourism 3 (1): 45-54.

Wijesuriya, G. 2015. Introducing people-centered approach to conservation and management of Hani Rice Terraces. In International workshop on the sustainable development of Honghe Hani Rice terraces: Proceedings. China: ICOMOS China.

2017. Towards the de-secularisation of heritage. Built Heritage 1: 1-15. https://doi.org/10.1186/BF03545659

Wright, J. 2016. Maritime archaeology and climate change: An invitation. Journal of Maritime Archaeology 11 (3): 255-270. http://www.jstor.org/stable/44508675 (accessed 9 August 2020).

Yakal, M. etal. 2020a. Education and heritage conservation in the Philippines: Archaeology's role in curricular change (Part 1). The SAA Archaeological Record 20 (3): 6-11. . 2020b. Education and heritage conservation in the Philippines: Archaeology's role in curricular change (Part 2). The SAA Archaeological Record 20 (4): 33-37. 